\title{
The Punitive Authorities of Independent Administrative Bodies and Its Role in Widening the Circle of Criminality
}

\author{
Dr. Rana Atour ${ }^{1,2}$ \\ ${ }^{1}$ University of Sharjah, United Arab Emirates \\ ${ }^{2}$ University of Jordan, Jordan \\ Correspondence: Dr. Rana Atour, University of Jordan, Jordan. E-mail: dr.ranaatour@yahoo.com \\ Received: June 14, 2017 \\ Accepted: July 18, 2017 Online Published: October 30, 2017 \\ doi:10.5539/ilr.v6n1p156 \\ URL: https://doi.org/10.5539/ilr.v6n1p156
}

\begin{abstract}
The punitive authorities of independent administrative bodies and their role in the widening circle of criminality have been the main focus of the study. The study has evaluated the criminal justice agencies, such as the French Constitutional Council and the European Court of Human Rights. Some domestic courts have been playing a vital role in enhancing the criminal proceedings for administrative offences. The role of penal legislation is essential to find, so the study reviewed the role of punitive authorities of independent administrative bodies in widening the circle of criminality. The independent administrative bodies in the economic activity lack legal guarantees and consecration that may be deliberated, and practiced under the guise of flexibility and speed to ensure effective economic state. Penal legislator should punish the offenders following the acts of disciplinary sanctions and administrative bodies. It has been observed that there are still some differences and imperfections in nature among countries concerning the national legislations. Decisions and judgments are issued by the administrative bodies; whereas, some large administrative bodies are found in the areas with greater economic activities. It has been found that there is lack of legal guarantees and consecration, which may be practiced to ensure the efficient economic state. The independent administrative authorities do not violate the legal provisions, which governs the sectors. The study has concluded that the power of punishment is no longer effective to the criminal judge. The independent administrative authorities do not violate the constitution and the legal provisions, governing the sectors.
\end{abstract}

Keywords: criminal, criminality, independent bodies, panel code, punitive

\section{Introduction}

Power is disciplinary to independent administrative bodies that is expressed in terms of judicial intervention in economic sectors. Decriminalization in a region is considered as a precursor to reliable and efficient judiciary. The principle of decriminalization allows the independent administrative bodies to intervene in the subjective criminalization in a non-traditional manner that encourages the authorities to function effectively. The phenomenon highlights the significance on the matter of supporting entities for the controlling bodies to ensure effectual action for countering criminalization (Delmas-Marty and Spencer, 2002). The study aims to address the subject of adopting authorities with the right to punish and provide justice from the independent administrations, belonging to the economic and financial sphere.

\subsection{Idea of Punitive Authority of Independent Administrative Bodies}

Due to persistent delay and inadequacy in justice, economic and financial sectors have emphasized on the emergence of punitive powers. However, the successful implementation of adjusting these independent bodies, regardless of the basic governing elements may enhance the essence of criminality. Therefore, it is considered necessary to first, apply the essential factors of punitive power to control and limit the expansion of the concept of 'criminal'. The concept expresses the authorization of punitive power of independent administrative bodies for a central goal of eliminating criminality. The phenomenon supports the development of new ways to punish the unlawful conduct. The aspect has been regulated in accordance to the goal of criminal policy and as a tool for firm service. 


\subsection{The First Requirement}

\subsubsection{Punitive Power to the Independent Administrative Bodies and the Phenomenon of Decriminalization}

In the concept of stabilizing independent administration with punitive power, the relationship between the independent administrative bodies and decriminalization is the main entity. It includes the transfer of repressive power of criminal judge in the favor of other bodies along with the independent administration. Moreover, it also involves the criminal penalties and administrative sanctions.

The idea has been adopted by Germany; however, France has not recognized the power of punishment administration for preserving the authority and reverence of power principle. The term "violation of regulations" has been introduced to punish the behavior that is recognized as violation (Benmakhlouf, 1984). Nonetheless, the concept aroused in 1970s, when the independent administrative bodies in France had to be emerged ultimately that were primarily dedicated to address the overruling control on certain sensitive sectors; including the economic and social life. Furthermore, the phenomenon arose more strongly in Jordan leading to the well-known establishment of independent administrative bodies.

In order to maintain the roles of independent bodies functioning as the punishing authorities, delegated tasks were assigned to the entities with regard to the new roles. For instance, the economic sector was assigned to monitor the market and organization of economic interests only. The practice followed the approach under the old competition law, Right of Criminal Justice, and the enactment of the Competition Act No. 33 of 2004. The aspect has been advanced as the jurisdiction for a criminal judge in the independent body, following in the terms stated by the Penal judge of Competition Council (Modern, 2001; Gazeir and Cannac, 1983).

\subsection{The Second Requirement}

\subsubsection{Punitive Power to the Independent Administrative Bodies and the Service Rules}

For attaining the perspective of effectual justice, decisions, and implementation, the independent administrative bodies are established and authorized to deal with the matters of economic and financial domain, primarily. The ultimate purpose of punitive power authorization is not the punishment of criminals with the absolute. Rather, the objective is to decriminalize the complex sector with technicalities. The transfer of power to punish refers to the independent administration. Following codes must be kept under consideration, while exercising the authorities in the delegated fields:

I. These sectors are incompatible to the system for declaring the imprisonments to the criminals. While, there are certain irregularities that must not be considered under the criminal acts, although the traditional penalties may not be effective on limiting the criminal conduct.

II. The emergence of punitive power to the independent administration has been an outcome of legislative criminality and offence that lead to the lack of regulation in certain cases (Ghannam, nd).

III. The criminal judge may neglect certain cases, considering the technicalities that may lead to the dismissal or withdrawal of the cases; causing inefficiency in the system.

IV. The authorization must also entail that these bodies are highly responsible for filling the gap in Criminal Card.

The provided conduct ensures that the purpose of attuning the economic field follows a nontraditional pattern, relying on the punitive power (Dr Sorour, 2000; Beard, 1989; Dr Behnam, 1986).

\subsection{The Third Requirement}

\subsubsection{Punitive Authority of Independent Administrative Bodies}

The purpose of punitive power authorization is delivered with the endorsement from the governmental bodies that primarily include the penal judges. The administrative bodies utilize the economic approach for the deliverance. The initial conduct involves the warning penalties as an example to the field. The declaration of power authorizes the independent administrative bodies to deter the sector on any criminal intention or conduct. It has been determined that the penalties may involve a varying amount of fine along with the profit that the offender may have earned form the deportment or the loss that has been avoided in the conduct for more than five times.

\section{Method}

The punitive authorities of independent administrative bodies and its role in the widening circle of criminality have been studied by considering the regulations of French Constitutional Council and European Court of Human Rights. The qualitative research design has been implemented for finding the inability of traditional methods in controlling the targeted sectors. The research has originated that the punitive authority is transferred to the criminal judge in favor of other bodies that are closer to targeted sectors, allowing fast intervention. It 
effectively distinguishes the administrative bodies that are empowered to inflict punishments, through a policy shift of decriminalization and replacing criminal penalties to administrative penalties. The data has been extracted from different search engines.

\section{Results}

\subsection{Flexible Punitive Power to Independent Administrative Bodies}

The punitive power of independent administrative bodies should not be exercised until and unless there is any identified or reported existence of irregularities, violations, or criminal conducts. The independent bodies tend to have a significant margin of appreciation in the offense and the necessary punishment.

\subsection{The First Requirement}

Administrative offence may consist of a physical act or/and mental influence.

\subsubsection{Physical Act}

Physical act constitutes of the foundation of administrative offense and represents a strong violation. The administration in such scenario is responsible for protecting the social interests of the industry in a broader sense. Databases have exhibited that most of the acts are of negative character and punishable that may include the lack of respect, un-cleared dues or non-compliance. The administrative bodies are responsible for interlinking two approaches of decriminalization and punishment. Jordan Securities Commission (JSC) and the Board of Commissioners have taken all the powers necessary to achieve the objectives in accordance with the provision of law. The investigation with the offender will be executed, if the board finds any offense, while preparing the laws and regulations related to the security approaches. The board shall be allowed to take any security measure against the person, who violates the provisions of law. The board may take one or more of the measures contained in Article 21 / B Securities Act, as well as respect for the powers of the Competition Directorate of the Ministry of Industry and Trade (Solomon, 2001; Delmas-Marty, 1992).

\subsubsection{Mental Influence}

In the cases that may involve mental influence on any criminal conduct, the penalty aims to ensure a balance between offence and harm. The harm is considered more as an effect on the community rather than the offender. Thus, penalties inflicted by independent administrative bodies in the economic and financial spheres must comply with the community's benefit.

\subsubsection{Fiscal Penalties}

The financial penalties, which directly affect the economy of a defaulting person, have been removed from the amount of financial debt. However, it shows the difference between the criminal and economic spheres of predetermined criminal fine in the Penal Code. The administration system follows a criteria to calculate fines that the offender must pay. It has been found in Article 21/b of Jordanian Securities Act that the person is obligated to pay fine if the Board finds that the person had committed any offense or has taken preparatory measures to violate any of the provisions of this Act.

\subsubsection{Non-Financial Penalties}

It has been observed that excessive use of financial sanctions detract other forms of punishments. Yet, it has also been found that the sanctions may heavily affect the professional impression in addition to the moral conduct of offender. Energy Control Commission can withdraw licenses temporarily of the enterprises for a certain period. They can pull a final exploitation license, or take precautionary measures if necessary (Dr Tigers, 2004).

\subsection{Independent Administrative Bodies and Their Control}

Independent administrative bodies have been deemed with many powers in exercising the punitive conduct for the criminal proceeding, both at the level of inspection and control.

\subsubsection{Inspection and Audit}

Inspection and audit include the investigation request, the attendance of witnesses, hear the statements under oath, and ask them to submit any documents and papers pertaining to the subject of investigation. These bodies might enlist the expertise and competence in the investigation, inspection, and audit procedures.

\subsection{Immediate and Interim Measures}

Independent administrative bodies have the power to take immediate measures that can be applied for the temporary period. JSC, for justified reasons, can connect for the protection of investors that may have an immediate impact in accordance with the following approach: 
I. Stop or suspend any activity relating to securities or certain financial paper.

II. Comment by public display of the financial paper.

III. Suspension of the licensee or adopted.

The Council creates immediate measures that may give the concerned person an opportunity to be heard or not, according to the public interest.

\subsection{Administrative Measures against Violators of the Law, Regulations, Directives and Decisions}

Independent administrative authorities have broad powers to take administrative measures against the violators of the law, regulations, directives, and decisions. The prominent administrative measures can be taken against offending dissemination of the investigation results. It might also order the offender for a defined period to be determined by the Council to stop committing or causing offence or preparatory actions. The Council has an authority to reply to an objection from the offender within two weeks from the date of receipt. If the response is negative or cannot be decided, the person may appeal the Board's decision to High Court of Justice.

\subsection{Substantive Legal Safeguards against Punitive Power to Independent Administrative Bodies}

The absence of a uniform legal system, known as rationing violations, and penalties by independent administrative bodies, distinctive rules for each economic sector makes it difficult to find substantive assurances. The guarantee is provided by the independent bodies that forms the basis of comparison in this study.

\section{Discussion}

\subsection{The First Requirement}

\subsubsection{The Principle of Offences and Penalties}

It requires the principle of legality and should be devoted to crime and punishment under the law to avoid any abuse.

\subsubsection{Legality of Offences}

The independent administrative bodies have considerable freedom in suppressing all possible offences. JSC have the penal authorities of provisions related to Securities Act and the regulations. Originally, the task has belonged to the legislations to identify offences and penalties, resulting from the legislative authority. It has been identified that the laws must establish the general framework of criminalization, leaving room for regulations (Frank, 1990).

\subsubsection{Legitimacy of Sanctions}

The study has not identified the matter to the independent administrative bodies, and measured the degree of legitimacy of sanctions in view of determining the maximum penalty. However, it has been determined that the private guarantee is available, when it comes to financial penalties and the revocation of the license or certification for a certain period.

\subsection{The Second Requirement}

\subsubsection{The Principle of Profile}

Profiling of an offender in the industry may affect people, who have not committed any crime. The approach must ensure adoption of responsibility, appropriate with the nature of the penalty. However, errors committed by a person must blended responsibility with the legal mandate and must look for the approval. If the practice is approved by the Board, it is the responsibility of person to be fixed in the case. French Court of Cassation has ruled that there is no legal provision that allows the committee to punish the subsidiaries, but these texts must punish the offenders and must ensure the right to defend.

\subsubsection{Presumption of Innocence}

It is the fundamental principle of democratic system, and the assumption of a fair trial. It is provided by the Code of Jordanian trials in addition to the constitutional references. It has been found that the Paris Court of Appeal has canceled financial penalty, imposed on Exchange Commission operations.

\subsection{Right to Defense}

It should be noted that the Jordanian legislature article 21/a of the Securities Act provides that: "The investigation or hearing to determine if the person has committed any offence or preparatory measures leading to commit breach of any of the provisions of the law and the regulations, directives and decisions must be adopted. It includes investigating the nature of the violation and the powers that has to be conducted. It includes 
notice of hearing the words, the nature of the offence, and the right statement heard." (Ch. Ferrari-Breeur, 2001).

\subsection{Combination of Constitutional Disputes}

The process of combining administrative penalties and criminal penalties for the same Act is highly critical. As to the principle of European Convention on human rights, this study contains exactly the same provisions of article 7/14 of the International Covenant on Civil and political rights. This reaffirms that "no one may be tried or punished for a crime he had been acquitted or convicted by a final judgment in accordance with the law and penal procedure of each country", as stipulated in principle legislation, article 58, The Jordanian Penal Code (Delmas-Marty, 1992).

\subsection{French Constitutional Council}

The French Constitutional Council has broadened the concept of retribution, and extended the principle of legitimacy on every penalty that involves punishment not just that it represents the criminal courts, but also the administrative justice. The Constitutional Council concluded that the principle of power separation does not constitute an obstacle towards an administrative authority in the exercise of punishment power. It can be viewed under two conditions: First that it is not about the penalties of deprivation of liberty. Secondly, the respect for constitutional rights and freedoms are particular to the rights of the defense (Stasiak, 1978; Cohen, 1987; Starlings, 1986).

\subsection{European Court of Human Rights}

European Court of human rights has developed a special concept under article 6/1 of European Convention on human rights. In accordance with conceptual framework, "each authority has to make binding decisions in the exercise of a judicial function based on rules of law to conduct regulator, all matter of jurisdiction". Thus, it appears that the European Court of human rights has adopted a purely physical concept of 'Court', regardless to the definition of national legislature. But, despite the above, the current situation attest a sort of stubbornness at the French national courts, which did not take the expanded interpretation of the European Court of human rights to the concept of 'criminal charge' provided for in article 6 of the European Convention on human rights (Bergoignan-Esper, 1973; Delmas-Marty, 1992).

\section{Conclusion}

It is required that the penal legislator often resorts to a policy of decriminalization, particularly in some of the financial and economic fields. It must assure to punish the offenders according to the acts of independent administrative bodies and disciplinary sanctions. National legislation in some countries, like Jordan and France, where there are still some imperfections and differences in nature among countries have implied the approach. Meetings before the independent administrative bodies approved the confidential nature, as the judgments or decisions issued by them. Finally, large independent administrative bodies are presented in the areas of economic activity that provide it with repressive authority to create new and specialized rules that vary from one body to another. Sometimes, it is found that there is a lack of legal guarantees and consecration that may be deliberated and practiced under the guise of flexibility and speed to ensure effective economic state. This phenomenon affects the rights of the bodies and establishes no legal stability. It has concluded that the power of punishment is no longer effective to the criminal judge. The independent administrative authorities do not violate the constitution and the legal provisions, governing the sectors. The body that formulates the law should differ from the procedure and the judgment.

\section{Acknowledgements}

The author is very thankful to all the associated personnel in any reference that contributed in/for the purpose of this research.

\section{References}

Behnam, R. (1986). Teach prevention calendar, established knowledge, Cairo.

Benmakhlouf, A., \& Faletti, F. (1984). The Ordnungszidrigkeiten in the Federal Republic of Germany, APC, n 7 , $74 \mathrm{~s}$.

Bergoignan-Esper, C. (1973). The separation of criminal justice functions, PUF.

Bezard., P. (1989). The new face of the board of stock exchange transactions, security and transparency of the financial market, INCD, 945.

Ch. Ferrari-Breeur. (2001). The contradiction and the administration power to impose sanctions, RFDA, No 01, 
36.

Cohen, C. (1987). The Court of Cassation and the separation of administrative and judicial authorities, Economica, $7 \mathrm{~s}$.

D. Uniyal., M., S. (1995). Precautionary measures in vagrancy laws on suspicion-events, legal library, Cairo.

Delmas-Marty, C. (1992). Punishing without judging from the administrative repression in administrative penal law? Economica, Paris, 55.

Delmas-Marty, M., \& Spencer, J. R. (2002). European criminal procedures (Vol. 25). Cambridge University Press.

Delmas-Marty. (1992). Criminal Trial and Human Rights, PUF, coll. The ways of the law, (1992): 10s; Dupont-Delestraint, "Criminal Law", Dalloz manual customary law. 15s.

Gazier., P., \& Cannac., Y. (1983). Study on independent administrative authorities EDCE, 13.

Ghannam., G. M. (1970). Administrative law. The Arabic Renaissance house, Cairo, 4.

Modern. (2001). In life business. P. 89.

Moderne Frank. (1990). Sanctions administrative et protection des libertés individuelles au regard de la Convention européenne des droits de l'homme. Petites Affiches, p. 15.

Pezard, A. (1993). The combination of criminal and administrative sanctions for legal persons in business law, P.A., No 120.

Salem, O. (1995). The legal regime of precautionary measures-a comparative study. The Arabic Renaissance house, Cairo.

Solomon, R. (2001). The A.A.I. sanctioning power in economic and financial matters and the fundamental guarantees. RDBF, 01, 41.

Sorour, A. F. (2000). Theory of gravity. Journal of law and Economics, (24).

Starlings, A., \& Fontenaux M., W. (1986). Specific guarantees in the acts of tax and customs administration, a decisive step, European Taxation, 27.

Stasiak, F. (1978). The nature of law enforcement powers to regulators and fundamental guarantees of the person, thesis, Nancy II, (1995): 7s. Mr. GUIBAL, "From proportionality” AJDA, 477.

Tigers M. S. (2004). Studies in criminal jurisprudence, The House of culture for publication and distribution, Oman.

\section{Copyrights}

Copyright for this article is retained by the author(s), with first publication rights granted to the journal.

This is an open-access article distributed under the terms and conditions of the Creative Commons Attribution license (http://creativecommons.org/licenses/by/4.0/). 